\title{
THE ROLE OF LAMININS IN CARTILAGINOUS TISSUES: FROM DEVELOPMENT TO REGENERATION
}

\author{
Y. Sun ${ }^{1,2}$, T.L. Wang ${ }^{1}$, W.S. Toh ${ }^{3}$ and M. Pei ${ }^{1,4,5, *}$ \\ ${ }^{1}$ Stem Cell and Tissue Engineering Laboratory, Department of Orthopedics, West Virginia University, \\ Morgantown, WV, USA \\ ${ }^{2}$ Department of Orthopedics, Orthopedics Institute, Subei People's Hospital of Jiangsu Province, \\ Yangzhou, Jiangsu, 225001, China \\ ${ }^{3}$ Faculty of Dentistry, National University of Singapore, Singapore, Republic of Singapore \\ ${ }^{4}$ Exercise Physiology, West Virginia University, Morgantown, WV, USA \\ ${ }^{5}$ Mary Babb Randolph Cancer Center, Robert C. Byrd Health Sciences Center, West Virginia University, \\ Morgantown, WV, USA
}

\begin{abstract}
As a key molecule of extracellular matrix, laminin provides a delicate microenvironment for cell functions. Recent findings suggest that laminins expressed by cartilage-forming cells (chondrocytes, progenitor cells and stem cells) could promote chondrogenesis. However, few papers outline the effect of laminins on providing a favorable matrix microenvironment for cartilage regeneration. In this review, we delineated the expression of laminins in hyaline cartilage, fibrocartilage and cartilage-like tissue (nucleus pulposus) throughout several developmental stages. We also examined the effect of laminins on the biological activities of chondrocytes, including adhesion, migration and survival. Furthermore, we scrutinized the potential influence of various laminin isoforms on cartilage-forming cells' proliferation and chondrogenic differentiation. With this information, we hope to facilitate an understanding of the spatial and temporal interactions between cartilage-forming cells and laminin microenvironment to eventually advance cell-based cartilage engineering and regeneration.
\end{abstract}

Keywords: Laminin, cartilage, regeneration, stem cell, matrix microenvironment.

*Address for correspondence: Ming Pei MD, PhD, Stem Cell and Tissue Engineering Laboratory, Department of Orthopedics, West Virginia University, PO Box 9196, One Medical Center Drive, Morgantown, WV 265069196, USA.

Telephone: $+13042931072 \quad$ Fax: $+13042937070 \quad$ Email: mpei@hsc.wvu.edu

\section{Introduction}

Cartilage is a specialized connective tissue with multi-component extracellular matrices (ECMs) that maintain its functionality. The major resident cells, chondrocytes, are responsible for the production of extracellular molecules, such as collagen, laminin and fibronectin (Tavella et al., 1997; Wilusz et al., 2014). Despite the progress in cartilage engineering (Bernhard and Vunjak-Novakovic, 2016), insufficient cartilage regeneration remains a significant clinical challenge, due to an absence of blood supply (Mobasheri et al., 2014; Roelofs et al., 2013).

Chondrocytes in cartilaginous tissues, such as hyaline cartilage, fibrocartilage and cartilage-like tissue (nucleus pulposus), are surrounded by a thin pericellular matrix (PCM), which is different from the territorial matrix and interterritorial matrix in both biochemical and biomechanical properties (Poole et al., 1984; Wilusz et al., 2014). Increasing evidence suggests that PCM contains laminin (LM), collagen type IV, nidogen and perlecan, which form the functional equivalent of a basement membrane (Kvist et al., 2008). Compared to the kidney, an organ highly enriched in glomerular basement membranes, articular chondrocytes exhibited significantly higher expression of LM $\alpha 4$, LM $\beta 1$ and nidogen-2, despite comparable levels of LM $\alpha 1, \mathrm{LM} \alpha 2$ and LM $\alpha 5$ (Kvist et al., 2008). The distribution and abundance of basement membrane components in cartilage are age-dependent. A gradual shift is distinct, from a diffuse expression in the territorial and interterritorial 
matrices of newborn mice toward a pericellular localization in mature cartilage, which then becomes less distinct once reaching old age (Kvist et al., 2008).

Basement-membrane proteins are present in several tissues and organs including skin and muscle, where they have been reportedly involved as critical components of the stem cell niche, regulating the functions of progenitor cells during healthy and diseased states (Boonen and Post, 2008; Fuchs, 2009). In articular cartilage, the staining of basement membrane proteins in the PCM was most prominent around cells of the cartilage superficial layer (Kvist et al., 2008), which is known as a niche for chondroprogenitors (Candela et al., 2014). Furthermore, a recent study found enhanced $\operatorname{LM} \alpha 1$, LM $\alpha 5$ and nidogen-2 in the PCM of osteoarthritic chondrocytes, suggesting that laminin promotes restoration of chondrocyte phenotypes (Schminke et al., 2016). The above evidence indicates that basement membrane components, especially laminin, might play a crucial role in regulating the fate and functions of chondroprogenitors and chondrocytes in cartilage repair and regeneration.

As a critical component in the basement membrane of various tissues, laminins, a family of heterotrimeric glycoproteins, contain one of five $\alpha$-chains, one of three $\beta$-chains and one of three $\gamma$-chains (Fig. 1A) (Aumailley, 2013; Schéele et al, 2007). Laminins were reported to direct various cellular functions, including adhesion, migration, growth, differentiation and apoptosis, through intercommunication with specific cell surface receptors, such as dystroglycan, sulfated glycolipids or particular integrins (Fig. 1B) (Aumailley and Rousselle, 1999; Colognato and Yurchenco, 2000; Eble, 2001; Häusler et al., 2002; Hohenester et al., 2013; Vuoristo et al., 2009; Yamada and Sekiguchi, 2015). Recent studies have implicated laminins in various disorders and diseases, such as hepatocellular carcinoma and congenital muscular dystrophy (Hall et al., 2007; Petz et al., 2012).

Increasing evidence indicates that ECMs can influence cartilage regeneration by regulating cell fate and functionality (Connelly et al., 2011; Lynch and Pei, 2014). Currently, the interaction between collagen or fibronectin and cartilage regeneration has drawn much attention (Aigner and Stöve, 2003; Stoffels et al., 2013). However, few review papers about potential roles of laminin and its isoforms on cartilage-forming cells for cartilage regeneration are available. In this review, the expression of laminins was outlined in various developmental stages of cartilage and cartilage-like tissues, including developing, adult and
A

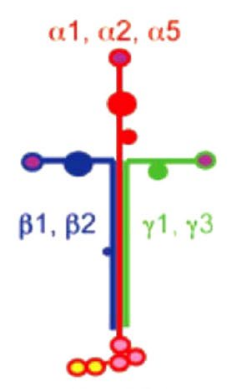

111,121

211, 221, 213

$511,521,522,523$

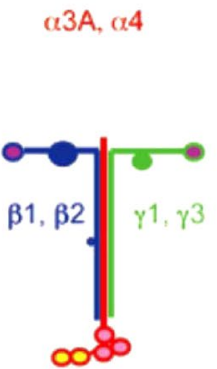

311,321

411, 421, 423

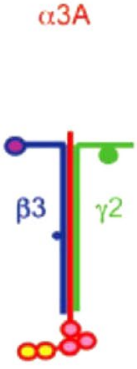

332A

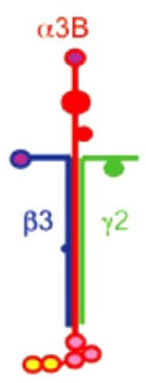

332B

B

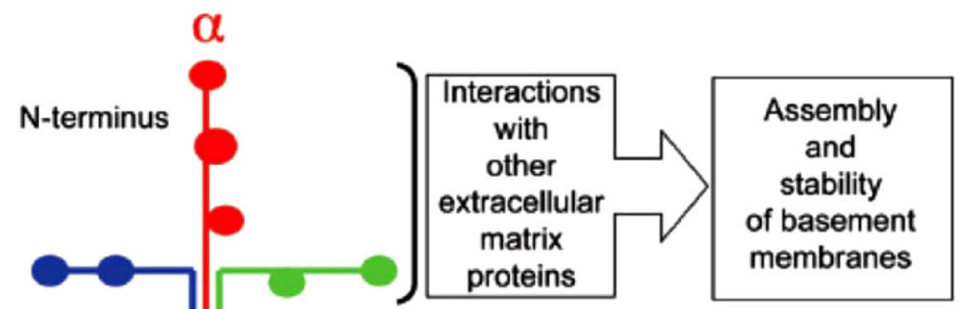

Fig. 1. Laminin family. (A) Known and/or predicted laminin heterotrimers. Eleven genes encode five $\alpha$, three $\beta$ and three $\gamma$ chains in the human genome. There are two transcripts for the LM $\alpha 3$ chain, one short $\alpha 3 \mathrm{~A}$ and one long $\alpha 3 \mathrm{~B}$ transcript. (B) Mapping of the major functions of laminins. The laminin short arms (N-terminus) are involved in architectural function within the basement membrane, while the end of the long arm (C-terminus) is typically involved in cellular interactions. Reprinted with permission from Aumailley (2013). 
pathological cartilage (Fig. 2). The effect of laminins on the biological activities of chondrocytes was also discussed, as well as stem cell chondrogenesis, in terms of adhesion, migration, survival, proliferation and chondrogenic differentiation (Fig. 3). This review allows an in-depth understanding of the role of laminins in providing a favorable matrix microenvironment for regeneration of cartilaginous tissues.

\section{Stage-dependent expression of laminin in cartilage and cartilage-like tissue}

Increasing evidence indicates that chondrocytes are responsible for the production of various laminins (Table 1a,b) that mainly locate in the PCM of cartilage (Foldager et al., 2014; SundarRaj et al., 1995). The expression of laminins varies during different developmental stages of cartilage and cartilage-like tissues (Fig. 2) (Dürr et al., 1996; Foldager et al., 2016; Lee et al., 1997).

\section{Developing stage}

A diverse distribution pattern of laminins was found in different developing stages of cartilage (Dürr et al., 1996; Häusler et al., 2002). Lee et al., (1997) found that laminin chains $(\alpha 1, \alpha 2, \beta 1, \beta 2$ and $\gamma 1)$, produced by chicken embryo sternal chondrocytes, exhibited an increased expression in aggregated cells during the maturation stage; LM-111 was detected primarily in the cytoplasm, rather than in the matrix of cartilaginous tissues. Kvist et al. (2008) reported that laminin, initially being widespread in newborn cartilage, organized into a pericellular distribution around the chondrocytes in mature cartilage. Similar to the location pattern in the superficial layer of adult articular cartilage, most laminins were detected in the resting zone in epiphyseal cartilage and expression decreased in the proliferating and hypertrophic zones (Dürr et al., 1996; Ustünel et al., 2003a). These findings indicate that laminins are dynamically expressed in a spatiotemporal manner.
A

B
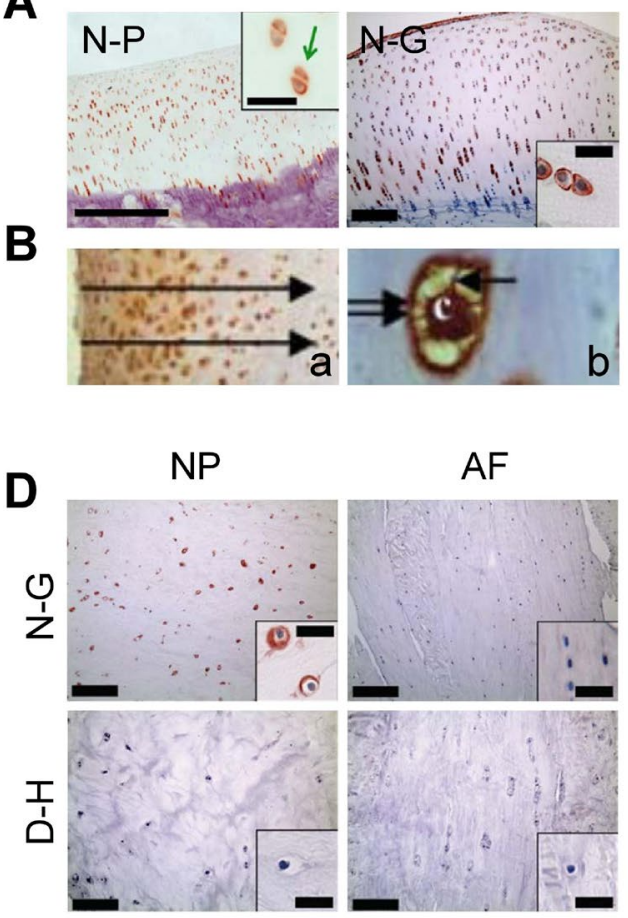

C
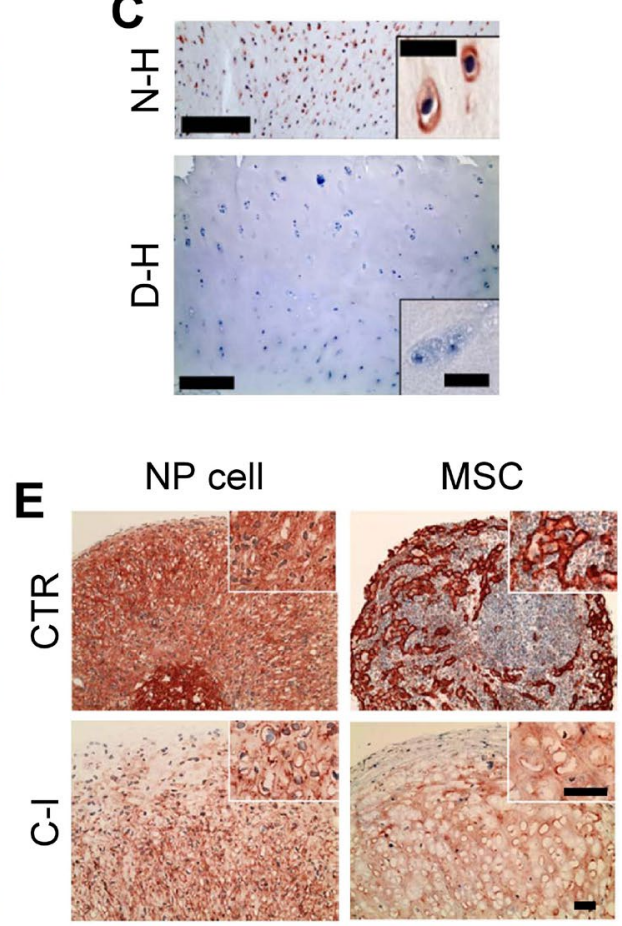

Fig. 2. Laminin expression in hyaline cartilage, fibrocartilage and cartilage-like tissues (NP), as well as cartilage-forming cells, under chondrogenic induction. (A) Normal articular cartilage from porcine (NP) (Foldager et al., 2016) and goat (N-G) (Foldager et al., 2014). Bars: large image $=200 \mu \mathrm{m}$, small image $=30 \mu \mathrm{m}(\mathrm{N}-\mathrm{P})$ and $20 \mu \mathrm{m}(\mathrm{N}-\mathrm{G})$. (B) A decrease of immunostaining from the periphery to deeper parts of human nasal septal cartilage in the direction of the arrows (a); immunostaining of laminin in chondrocyte cytoplasm (c), projections (arrows) and pericellular rings (double arrows) is strong (b) (Üstünel et al., $2003 \mathrm{~b}$ ). In the original publication, scale bars were not shown but magnification values of (a) $\times 25$ and (b) $\times 100$ were given. (C) Laminin-positive pericellular stain was only detectable in normal human (N$\mathrm{H})$ articular cartilage rather than degenerated human (D-H) articular cartilage (Foldager et al., 2014). Bars: large image $=200 \mu \mathrm{m}$, small image $=20 \mu \mathrm{m}$. (D) Laminin-positive stain was only stained in normal goat (N-G) NP tissue rather than in the degenerated human (D-H) NP tissue and both normal goat and degenerated human AF tissues (Foldager et al., 2014). Bars: large image $=200 \mu \mathrm{m}$, small image $=20 \mu \mathrm{m}$. (E) Immunohistochemistry of laminin in goat NP cell and bone marrow-derived MSC pellets after $14 \mathrm{~d}$ of chondrogenic induction (C-I). The group without treatment serves as a control (CTR) (Toh et al., 2013). Scale bar: $50 \mu \mathrm{m}$. Reprinted with permission from Foldager et al. (2014), Foldager et al. (2016), Toh et al. ( 2013) and Üstünel et al. ( 2003b). 
During the development of intervertebral disc (IVD), laminins gradually appear but have a shifting pattern in different developmental stages. Using immunofluorescence labelling procedures, Hayes et al. (2001) found that laminin was distributed pericellularly in developing nucleus pulposus (NP), annulus fibrosus (AF) and vertebral bodies of rats. Furthermore, Toh et al. (2013) cultured goat NP cells in a pellet system to form cartilaginous tissue and found that laminins were expressed with an orderly shift from a diffused distribution to a defined pericellular localization. Interestingly, dramatic differences in laminin expression existed in the cells between the immature NP and AF region. Chen et al. (2009) found higher levels of the LM $\alpha 5$ chain and related receptors in immature rat and pig NP regions compared to the $\mathrm{AF}$, but $\mathrm{AF}$ regions had more intense expression and, frequently, more LM $\alpha 1$ chains than NP tissue. These studies demonstrate that, similar to the pattern in cartilage, laminins are continuously expressed in all developing stages in cartilage-like tissues and show a region-specific expression pattern.

In addition, laminins were found in tissue engineered cartilaginous constructs. For instance, an extensive expression of laminin was observed in vitro following three weeks of chondrogenic culture of bone marrow-derived mesenchymal stem cells (MSCs) in both poly (ethylene glycol) diacrylate (PEGDA) hydrogel (Köllmer et al., 2012) and hyaluronic acid- based hydrogel (Toh et al., 2012). Similarly, Jeng et al. $(2012,2013)$ found widespread expression of laminins throughout the ECM, in both engineered cartilage constructs and reparative tissues, following implantation of chondrocyte-seeded constructs in caprine cartilage defects - although the expression of laminin appeared diffused compared to the pericellular staining pattern observed in normal adult cartilage.

\section{Adult stage}

As an important ECM component, in adult cartilage, laminins participate in the organization of the basement membrane-like structure around the chondrocytes. Dürr et al. (1996) demonstrated that laminins were mainly located in the PCM of human adult articular cartilage, which was further verified in goat and bovine cartilage (Foldager et al., 2014; Kvist et al., 2008). Ustünel et al. (2003b) found a similar pattern of laminin expression in human nasal septal cartilage with higher expression in the periphery of the cartilage, which gradually decreased in deeper zones. Laminins were also found in meniscus and some other fibrocartilage (Chu et al., 2017; Foldager et al., 2014; Salter et al., 1995). However, the expression of laminins displayed a more pericellular diffusion in menisci, which was different from the well-defined pericellular localization of articular cartilage (Foldager et al., 2014). Similarly, in the
A

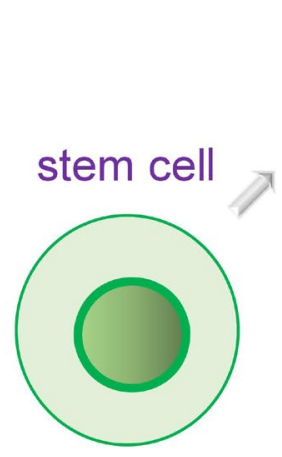

\section{laminin}

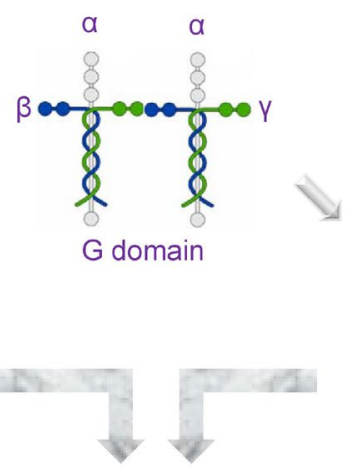

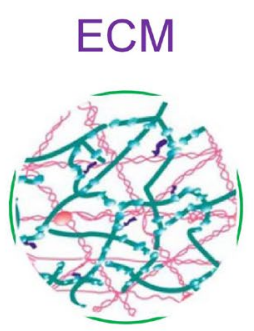

B

chondrogenesis

Fig. 3. The expression and function of laminin during cartilaginous tissue regeneration. (A) Stem cells produce laminin and form the ECM (Laperle et al., 2015; Rodin et al., 2014). (B) After adhesion, laminin promotes stem cell proliferation and regulates chondrogenesis in vitro (Hashimoto et al., 2006; Toh et al., 2013). 
Table 1a. Laminin expression pattern in hyaline cartilage and fibrocartilage. Abbreviation: ACI: autologous chondrocyte implantation; AF: annulus fibrosus; DO: day old; MO: month old; NP: nucleus pulposus; OA: osteoarthritis; OARSI: Osteoarthritis Research Society International; WO: week old; YO: year-old.

\begin{tabular}{|c|c|c|c|c|c|}
\hline & Age & Species & LM types & Location pattern & Reference \\
\hline \multirow{26}{*}{ 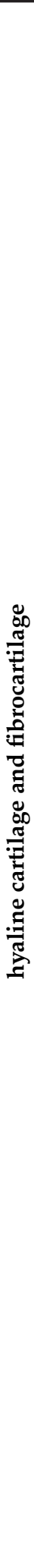 } & embryo & chicken & $\begin{array}{c}\mathrm{LM} \alpha 1, \alpha 2, \beta 1, \\
\beta 2, \gamma 1\end{array}$ & sternal cartilage & Lee et al., 1997 \\
\hline & embryo & mouse & $\begin{array}{c}\mathrm{LM} \alpha 1, \alpha 2, \beta 1 \\
\beta 2, \gamma 1\end{array}$ & 14-DO limb bud cartilage & Lee et al., 1997 \\
\hline & $\begin{array}{l}\text { embryo/ } \\
\text { neonate }\end{array}$ & rat & $\mathrm{LM}$ & AF tissue & Hayes et al., 2001 \\
\hline & fetus & human & LM & $\begin{array}{l}\text { 16-WO knee joint cartilage (articular, } \\
\text { epiphyseal and meniscus) }\end{array}$ & Salter et al., 1995 \\
\hline & fetus & human & $\mathrm{LM} \alpha 1, \beta 1, \gamma 1$ & $\begin{array}{l}\text { resting-zones of 30-WO tibia } \\
\text { epiphyseal cartilage }\end{array}$ & Dürr et al., 1996 \\
\hline & fetus & human & $\operatorname{LM} \gamma 2$ & cartilage at early stages of gestation & Lu et al., 2001 \\
\hline & neonate & mouse & LM & mandibular condyle cartilage & Silbermann et al., 1990 \\
\hline & $\begin{array}{l}\text { newborn } \\
\text { /adult }\end{array}$ & mouse & $\begin{array}{c}\mathrm{LM} \alpha 1, \alpha 2, \alpha 4, \alpha 5 \\
\beta 1, \gamma 1\end{array}$ & femoral head cartilage & Kvist et al., 2008 \\
\hline & $\begin{array}{l}\text { childhood } \\
\text { /adolescent }\end{array}$ & human & LM & $\begin{array}{l}\text { resting-zones of growth plate } \\
\text { cartilage }\end{array}$ & Häusler et al., 2002 \\
\hline & immature & rat & LM & $\begin{array}{l}\text { 60-DO humerus proximal epiphyseal } \\
\text { cartilage (articular cartilage and } \\
\text { epiphyseal growth plate) }\end{array}$ & Ustünel et al., 2003a \\
\hline & immature & rat & LM & $\begin{array}{l}\text { temporomandibular joint condylar } \\
\text { cartilage and disc tissue }\end{array}$ & Chu et al., 2017 \\
\hline & immature & porcine & $\mathrm{LM} \alpha 1$ & 3-MO AF tissues & Chen et al., 2009 \\
\hline & immature & rat & $\mathrm{LM} \alpha 1$ & 1-MO AF tissues & Chen et al., 2009 \\
\hline & immature & porcine & $\mathrm{LM} \gamma 1$ & AF tissues & Gilchrist et al., 2007 \\
\hline & adult & goat & LM & $\begin{array}{l}\text { normal articular cartilage, meniscus } \\
\text { and calcified cartilage }\end{array}$ & Foldager et al., 2014 \\
\hline & adult & bovine & LM & $\begin{array}{l}\text { 18-MO metacarpophalangeal joint } \\
\text { cartilage }\end{array}$ & Kvist et al., 2008 \\
\hline & adult & human & $\mathrm{LM} \alpha 1, \beta 1, \gamma 1$ & upper zone of articular cartilage & Dürr et al., 1996 \\
\hline & adult & human & LM & nasal cartilage & SundarRaj et al., 1995 \\
\hline & adult & human & LM & $\begin{array}{c}\text { mandibular condyles cartilage } \\
\text { degenerative lesion }\end{array}$ & Ishibashi et al., 1996 \\
\hline & adult & human & LM & nasal septal cartilage & Ustünel et al., 2003b \\
\hline & adult & human & $\mathrm{LM} \alpha 4$ & $\begin{array}{l}\text { high expression in arthritis cartilage } \\
\text { lesions grade IV hypertrophic } \\
\text { chondrocyte clusters according to the } \\
\text { OARSI criteria for osteoarthritis }\end{array}$ & Fuerst et al., 2011 \\
\hline & adult & human & LM & normal articular cartilage & Foldager et al., 2014 \\
\hline & adult & human & LM & $\begin{array}{c}\text { normal articular cartilage; no } \\
\text { expression in traumatically damaged } \\
\text { cartilage and clinically failed repair } \\
\text { cartilage }\end{array}$ & Foldager et al., 2016 \\
\hline & adult & human & $\operatorname{LM} \alpha 1, \alpha 5$ & healthy and OA articular cartilage & Schminke et al., 2016 \\
\hline & adult & mouse & $\begin{array}{c}\mathrm{LM} \alpha 1, \alpha 2, \beta 1 \\
\beta 2, \gamma 1\end{array}$ & 3-WO knee joint cartilage & Lee et al., 1997 \\
\hline & adult & porcine & LM & $\begin{array}{l}\text { normal articular cartilage/repair } \\
\text { tissue after scaffold-seeded ACI }\end{array}$ & Foldager et al., 2016 \\
\hline
\end{tabular}


Table 1b. Laminin expression pattern in cartilage-like tissues. Abbreviation: ACI: autologous chondrocyte implantation; AF: annulus fibrosus; DO: day old; MO: month old; NP: nucleus pulposus; OA: osteoarthritis; OARSI: Osteoarthritis Research Society International; WO: week old; YO: year-old.

\begin{tabular}{|c|c|c|c|c|c|}
\hline & Age & Species & LM types & Location pattern & Reference \\
\hline \multirow{9}{*}{ 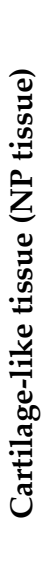 } & $\begin{array}{l}\text { embryo/ } \\
\text { neonate }\end{array}$ & rat & LM & NP and notochordal cell surface & Hayes et al., 2001 \\
\hline & immature & porcine & $\mathrm{LM} \gamma 1$ & NP tissue & Gilchrist et al., 2007 \\
\hline & immature & porcine & $\mathrm{LM} \gamma 2$ & 3-6-MO NP tissue & Gilchrist et al., 2011a \\
\hline & immature & rat & $\mathrm{LM} \gamma 2$ & 1-MO NP tissue & Gilchrist et al., 2011a \\
\hline & $2-, 12-, 35-Y O$ & human & $\mathrm{LM} \alpha 5, \gamma 1$ & $\begin{array}{l}\text { age-dependent decrease in NP tissue, } \\
\text { particularly LM } \gamma 1\end{array}$ & Chen et al., 2009 \\
\hline & 3-, 24-MO & porcine & $\mathrm{LM} \alpha 1, \alpha 5$ & NP tissues & Chen et al., 2009 \\
\hline & $1-, 12-\mathrm{MO}$ & rat & $\mathrm{LM} \alpha 1, \alpha 5$ & NP tissues, particularly LM $\alpha 5$ & Chen et al., 2009 \\
\hline & mature & goat & $\mathrm{LM}$ & normal NP tissues & Foldager et al., 2014 \\
\hline & mature & goat & $\mathrm{LM}$ & NP cells, pellet, and native tissues & Toh et al., 2013 \\
\hline
\end{tabular}

rat temporomandibular joint (TMJ), laminins were found present in the PCM surrounding individual chondrocytes, but were predominately distributed in the proliferative zone of the condylar cartilage (Chu et al., 2017).

In adult cartilage-like tissues, laminins produced by mature goat NP cells in a pellet culture system also formed ECMs with a pericellular distribution (Toh et al., 2013). Moreover, many laminins and some subunits, such as LM $\alpha 1, \alpha 5$ and $\gamma 1$, were located in the PCM of goat, porcine, human and rat NP cells (Chen et al., 2009; Foldager et al., 2014; Toh et al., 2013). Similar to the findings in immature IVD, laminins produced by mature NP cells showed a region-specific expression pattern. Chen et al. (2009) found that the LM $\alpha 5$ chain had more significant expression in NP than AF regions, although with lower expression compared to immature NP tissues.

\section{Pathological stage}

Disorders of ECM formation are the significant characteristics of cartilage degradation, which can influence subsequent reactive processes for degeneration (Lu et al., 2011; Moazedi-Fuerst et al., 2016). In most studies, the expression of laminins significantly decreased or disappeared in degenerative articular cartilage and menisci (Foldager et al., 2014; Foldager et al., 2016; Ishibashi et al., 1996). Also, the expression of laminins showed an age-related change in degenerative cartilage (Ishibashi et al., 1996). Considering the prominent expression in developing and normal cartilage, as well as the negative expression in traumaticallydamaged cartilage and cartilage that failed clinical repair (Foldager et al., 2016), laminin could serve as an early marker for cartilage degeneration by observing its dynamic expression. Interestingly, the diverse expression of laminins in degenerative cartilage also indicate their role in cartilage degeneration
(Moazedi-Fuerst et al., 2016; Schminke et al., 2016). For example, LM $\alpha 4$, with significantly higher expression in severely degenerated sites, compared with mild areas, in human osteoarthritic cartilage, co-localized with syndecan-4 around hypertrophic chondrocytes and perpetuated cartilage damage in osteoarthritic cartilage, which suggested that LM $\alpha 4$ played a deleterious role in cartilage degeneration (Fuerst et al., 2011). Therefore, laminins may be a possible regulator in degenerative cartilage.

Similar findings have been uncovered in degenerative cartilage-like tissues. Chen et al. (2009) reported that laminin chains decreased in older specimens compared with immature NP, which was inferred as a cause of decreased cellularity in older tissues. Foldager et al. (2014) found significant expression of laminin in healthy goat NP, but failed to find laminin expression in human degenerative NP tissue using immunohistochemical analysis. Collectively, these findings suggest that laminins are altered in expression pattern and/or decreased in quantity in conjunction with the degeneration of the cartilage-like tissues, implicating the role of laminin in cartilage degeneration.

The effect of laminin on chondrocyte function Laminins are important cell-adhesive ligands and are mainly present around chondrocytes. The interactions between laminins and chondrocytes can regulate many cell-biological functions, such as adhesion, migration and survival (Bulić, 1996; Francisco et al., 2014; SundarRaj et al., 1995).

\section{Cell adhesion}

As major adhesive molecules of ECM in cartilaginous tissues, laminins exert a prominent role in regulating cell-cell or cell-matrix interactions. Many studies demonstrated that LM-511, LM-332 and LM111 have strong cell attachment capabilities in 
chondrocytes and NP cells (Dürr et al., 1996; Gilchrist et al., 2011a; Gilchrist et al., 2011b). For example, Dürr et al. (1996) demonstrated that human fetal chondrocytes could attach to the E8 fragment of LM-111, mainly depending on the interaction with integrin $\alpha 6 \beta 1$. Moreover, Francisco et al. (2013) found that supplementation with LM-111 in an injectable functionalized hydrogel promoted adhesion of porcine NP cells. Multiple cell surface receptors mediated the adhesion of laminins with chondrocytes and NP cells (Dürr et al., 1996; Gilchrist et al., 2007; Nettles et al., 2004), especially through integrins (Loeser, 2014). Blocking studies indicated that integrin $\beta 1$ or $\alpha 6 \beta 1$ were primary receptors for strong cell attachment in human chondrocytes and NP cells (Bridgen et al., 2013; Dürr et al., 1996). These results demonstrate that laminins can potentiate the strength of cell adhesion by binding to integrins. Furthermore, adhesion capacity is significantly different among various types of laminin. For instance, Gilchrist et al. (2011a) demonstrated by analysis of adherent numbers and detachment strength in immature porcine NP cells, that LM-511 and LM-332 displayed stronger effects than other matrices, such as LM-111, type II collagen and fibronectin. Diminished NP cell adhesion on LM-111 is consistent with its relatively low expression in porcine, rat or human immature NP tissues (Chen et al., 2009; Gilchrist et al. 2011a). The discrepancy in adhesion capacities of laminins may be explained by receptor binding differences; in other words, a prominent integrin subunit may exist in special cell types and regions.

\section{Cell migration}

Under stimuli of various matrices, chondrocytes are able to migrate to regulate biological activities. Bulić (1996) demonstrated that laminin and lamininderived peptides promoted maximal bovine articular chondrocyte migration, but migration subsequently decreased when subjected to a higher compound concentration. Moreover, Moazedi-Fuerst et al. (2016) found that in vitro blocking of LM $\alpha 4$ significantly decreased cluster formation of human osteoarthritic chondrocytes. Interestingly, they found that LM $\alpha 4$ was important for targeted migration but did not inhibit movement. Furthermore, immature porcine NP cells could attach rapidly to LM-511 and LM-332 substrates, suggesting the positive role of laminin in regulating migration of NP cells (Gilchrist et al., 2011a). These studies suggest that laminins have a regulatory effect on migration of cartilage-forming cells.

Even though laminins are actively involved in cell migration (Gorfu et al., 2008; Nguyen-Ngov et al., 2012), the detailed mechanisms underlying the effects of laminins on chondrocyte migration are still unclear. Matrix metalloproteinases (MMPs), which are responsible for the degradation of collagen type II and digestion of proteoglycan and other noncollagen proteins in osteoarthritis, exerted regulative roles in cell migration (Laurent et al., 2003; Li et al.,
2013; Moazedi-Fuerst et al., 2016). Laminins might control chondrocyte migration by regulating MMPs; for example, LM $\alpha 4$ blockade could downregulate MMP3 and upregulate MMP16 (Fuerst et al., 2011; Moazedi-Fuerst et al., 2016).

\section{Cell survival}

Laminins are known to promote cell survival in several cell types by mediating cell-laminin interactions in response to various environmental conditions in vitro (Ekblom et al., 2003; Gu et al., 2002). Bulić (1996) demonstrated that IKVAV sequence-containing peptide derived from the laminin could promote proliferation of bovine articular chondrocytes, suggesting a positive role of laminin in promoting chondrocyte survival. Furthermore, an increasing number of studies have demonstrated that laminin had the same effect in promoting NP cell survival (Francisco et al., 2014; Gilchrist et al., 2011a). Francisco et al. (2014) found that LM-111 could significantly increase viability of NP cells in a three-dimensional (3D) poly (ethylene glycol) (PEG)-laminin hydrogel compared to blank gels - despite the inhibition of cell viability by PEG hydrogel alone - suggesting that LM-111 retained the bioactivity of the native protein in 3D PEG hydrogels and cell survival was mainly mediated by cell-LM-111 interactions. These results also suggest that laminin may be a survival ligand for NP cells. However, contrary reports also exist showing that laminin may have different effects on chondrocyte survival. Chu et al. (2017) demonstrated that, as opposed to collagen types IV and VI, laminin had no effect on cell viability and proliferation of rat TMJ condylar and disc chondrocytes. In another example, Fuerst et al. (2011) found that MMP3 expression was significantly downregulated in human chondrocytes from mild osteoarthritis after neutralizing LM $\alpha 4$. Considering the damaging effect of MMP3 on cartilage, the results demonstrate that LM $\alpha 4$ has the opposite effect on chondrocyte survival and may aggravate cartilage damage in osteoarthritis. This disparity in chondrocyte survival response to laminins may be explained by different responses of chondrocytes to various laminin isoforms.

\section{The effect of laminin on stem cell proliferation}

Cartilage-forming cells, such as stem cells and progenitor cells, are able to differentiate into a chondrogenic lineage under specific stimulation and they play important roles in cartilage regeneration ( $\mathrm{Li}$ et al., 2014; Pizzute et al., 2016; Toh et al., 2014; Zhang et al., 2015). Due to the increasing loss of proliferation capacity and risk of spontaneous differentiation resulting from replicative senescence, it is difficult to obtain a sufficient number of stem cells to differentiate into chondrocytes for autologous transplantation ( $\mathrm{Li}$ and Pei, 2012; Toh et al., 2016b). Therefore, acquisition of a sufficient number of stem cells by increasing proliferation before inducing differentiation is a critical step for cartilage regeneration (Pei, 2017). 


\section{Positive effects}

Although there are few reports on the effect of laminins on chondrocyte survival, recent studies have shown the roles of laminins in regulating proliferation and apoptosis of chondroprogenitor cells, such as mouse teratocarcinoma-derived chondrogenic cell line (ATDC5). Choi et al. (2010) demonstrated that laminin could significantly increase proliferation and decrease apoptosis of ATDC5 cells, when cultured on laminin-derived peptide-coated surfaces of hybrid mussel adhesive proteins (fp-151) compared with those on non- and bare fp-151-coated surfaces. These results indicate that activation of integrin signaling by laminin might be responsible for enhanced cell survival in ATDC5 cells. In addition, LM-111, LM-332 and Matrigel (the trade name for a gelatinous protein mixture secreted by Engelbreth-Holm-Swarm mouse sarcoma cells, BD Biosciences, San Jose, CA, USA) could efficiently promote proliferation of mouse neural progenitor cells derived from induced pluripotent stem cells (iPSCs) (Komura et al., 2015). Considering that hyaline cartilage, such as nasal septal cartilage, emerges from neural crest progenitor/stem cells (Crane and Trainor, 2012; Somoza et al., 2014), regulation of progenitor cells' proliferation by laminins may be a promising approach to ensure substantial cell quantity for applications in regenerative medicine (Leiton et al., 2015; Ortinau et al., 2010).

As an important molecule of ECM, many studies have demonstrated the positive effect of laminins on promoting proliferation in various stem cells (Table 2). Increasing evidence suggests that specific laminin isoforms could enhance the proliferation capacity of adult stem cells when cultured on a coated or soluble laminin environment (He et al., 2013; Lam et al., 2012; Lindner et al., 2010; Mathews et al., 2012). Indeed, previous studies have shown that laminins are secreted by various stem cell types, implying the role of laminins in regulating stem cell renewal and differentiation (Toh et al., 2013; Toh et al., 2016a). Hashimoto et al. (2006) found that LM-332 and LM$511 / 521$, but not LM-111 and LM-211/221, could promote the adhesion of human MSCs with LM-332 having the largest number of cells attached and spread well within $10 \mathrm{~min}$. Also, they found that LM332 promoted proliferation of human MSCs through interactions with integrins $\alpha 3 \beta 1$ and $\alpha 6 \beta 1$.

Pluripotent stem cells (PSCs), consisting of embryonic stem cells (ESCs) and iPSCs, have significant abilities to differentiate into chondrocytes (Ko et al., 2014; Toh et al., 2010). Multiple studies have shown that laminins, normally expressed by these PSCs, were indicative of the cells' functions (Laperle et al., 2015; Vuoristo et al., 2009). For example, laminins promoted strong renewal and stimulated efficient proliferation of PSCs as a robust substratum (Lam et al., 2012; Rodin et al., 2010; Rodin et al., 2014; Vuoristo et al., 2009). By comparing the effects on mouse ESC proliferation of different laminin isoforms, Domogatskaya et al. (2008) found that LM-
511 and LM-332 could promote ESC proliferation, while LM-111, Matrigel and gelatin caused rapid differentiation. The finding was later confirmed in a study by Miyazaki et al. (2012), who reported that the E8 fragments of LM-511 and LM-332 interacted with integrin $\alpha 6 \beta 1$ to promote robust proliferation for up to ten passages of human ESCs and iPSCs in their undifferentiated state.

Although the above studies verify that laminins are effective in promoting stem cell proliferation, the results from the two-dimensional (2D) environment in vitro could be different from those of the 3D ECM microenvironment in vivo, in which stem cells mainly reside (Pei et al., 2011). Thus, scaffold modification to incorporate laminins could be applied to promote bioactivity of scaffolds in the 3D culture system (Brynda et al., 2009; Heydarkhan-Hagvall et al., 2012; Kang et al., 2012). He et al. (2013) utilized laminin to modify poly(l-lactide) scaffolds and found that larger amounts of laminins could promote proliferation of mouse neonatal stem cells. The study also suggested that laminin modification was essential for stem cells to build up a 3D growth microenvironment and that laminin concentration could affect cell proliferation. Taken together, laminins exert significant effects on promoting stem cell proliferation in both the $2 \mathrm{D}$ and 3D microenvironment.

\section{Negative effects}

Although most reports demonstrate that laminins can promote stem cell proliferation, some studies show that laminins have, to a certain degree, inhibitory effects on stem cell and progenitor cell proliferation, by reducing cell number and viability during expansion (Abay et al., 2016; Celebi et al., 2011; Heydarkhan-Hagvall et al., 2012; Ode et al., 2010; Qian and Saltzman, 2004). Seeger et al. (2015) found that LM-211, LM-411, LM-511 and LM-521 inhibited proliferation of undifferentiated MSCs, but upon myogenic differentiation, only LM-521 significantly enhanced proliferation of myogenically differentiating cells. In another study, LM-111 was found to inhibit proliferation by triggering ESC differentiation within two weeks, while LM-411 failed to support survival of ESCs (Domogatskaya et al., 2008). These findings suggest that laminins may have negative effects on stem cell proliferation by activating differentiation and/or reducing the adhesion of stem cells. Furthermore, Arulmoli et al. (2016) found that human neural stem/progenitor cells grew well in fibrin and combination scaffolds with hyaluronic acid, but the addition of laminin could not significantly increase cell proliferation by quantitation of the Ki-67 immunostaining-positive cells. Interestingly, Matrigel, which contains laminins, collagens, heparin sulfate proteoglycans and growth factors, induced significant improvement in cell proliferation (Addington et al., 2014; Vuoristo et al., 2009), suggesting that a combination of ECM components and inherent growth factors affects cell proliferation. 
Table 2a. Positive effect of laminins on stem cells' proliferation. Abbreviation: ADSCs: adipose derived MSCs; BMMNCs: bone marrow mononuclear cells; BMSCs: bone marrow derived MSCs; C17.2 cell: neonatal mouse cerebellum stem cell; CFU-F: colony-forming unit fibroblast; ECM gel: basement membrane extracellular matrix protein gel, from Sigma-Aldrich; ESCs: embryonic stem cells; HUCB: human umbilical cord blood; iPSCs: induced pluripotent stem cells; LDH: lactate dehydrogenase; LM: laminin; NSCs: neural stem cells; NSPCs: neural stem/precursor cells; PLLA: poly-L-lactide; Matrigel: the trade name for a gelatinous protein mixture secreted by Engelbreth-Holm-Swarm (EHS) mouse sarcoma cells.

\begin{tabular}{|c|c|c|c|c|c|}
\hline Age & Species & Stem cell type & Assay & Results & Reference \\
\hline adult & human & ADSCs & cell counting & $\begin{array}{l}\text { LM coating promoted cell } \\
\text { proliferation }\end{array}$ & Lam et al., 2012 \\
\hline adult & human & ADSCs & LDH assay & $\begin{array}{c}\text { LM coating increased cell } \\
\text { proliferation }\end{array}$ & Keller et al., 2016 \\
\hline adult & human & BMSCs & cell counting & $\begin{array}{l}\text { LM-111, LM-332 or ECM gel } \\
\text { promoted cell proliferation }\end{array}$ & Lindner et al., 2010 \\
\hline adult & human & BMSCs & cell counting & $\begin{array}{l}\text { LM coating promoted cell } \\
\text { proliferation }\end{array}$ & Mathews et al., 2012 \\
\hline adult & human & BMSCs & cell counting & $\begin{array}{l}\text { LM-332 coating promoted cell } \\
\text { growth; LM-511/521 or LM-111 } \\
\text { slightly promoted growth }\end{array}$ & Hashimoto et al., 2006 \\
\hline adult & human & $\begin{array}{l}\text { STRO-1(+) } \\
\text { BMMNCs }\end{array}$ & $\begin{array}{l}\text { CFU-F } \\
\text { efficiency }\end{array}$ & $\begin{array}{l}\text { LM coating increased the } \\
\text { amount and size of colonies }\end{array}$ & Gronthos et al., 2001 \\
\hline neonate & mouse & C17.2 cell & $\begin{array}{l}\text { MTS cell } \\
\text { proliferation } \\
\text { assay } \\
\end{array}$ & $\begin{array}{c}\text { LM modified PLLA nanofibrous } \\
\text { scaffolds enhanced cell } \\
\text { proliferation }\end{array}$ & He et al., 2013 \\
\hline postnatal & human & NSPCs & $\begin{array}{c}\text { neurosphere } \\
\text { and cell } \\
\text { counting }\end{array}$ & $\begin{array}{l}\text { LM coating increased cell } \\
\text { number and neurosphere size }\end{array}$ & Flanagan et al., 2006 \\
\hline fetus & human & NSCs & $\begin{array}{l}\text { neurosphere } \\
\text { counting }\end{array}$ & $\begin{array}{l}\text { LM coating increased primary } \\
\text { neurosphere formation }\end{array}$ & Hall et al., 2008 \\
\hline fetus & human & $\begin{array}{l}\text { HUCB-derived } \\
\text { NSCs }\end{array}$ & $\begin{array}{l}\text { Ki67+ cells } \\
\text { counting }\end{array}$ & $\begin{array}{l}\text { LM coating promoted cell } \\
\text { proliferation rate }\end{array}$ & Szymczak et al., 2010 \\
\hline embryo & human & ESCs & colony size & $\begin{array}{l}\text { LM-511 or Matrigel rather } \\
\text { than LM-111 promoted cell } \\
\text { proliferation }\end{array}$ & Vuoristo et al., 2009 \\
\hline embryo & human & ESCs & $\begin{array}{l}\text { cell counting } \\
\text { and average } \\
\text { contact area }\end{array}$ & $\begin{array}{l}\text { LM-511 coating promoted cell } \\
\text { proliferation for at least } 28 \\
\text { passages }\end{array}$ & Rodin et al., 2010 \\
\hline embryo & human & ESCs & $\begin{array}{l}\text { growth curve } \\
\text { and colony } \\
\text { counting }\end{array}$ & $\begin{array}{l}\text { LM-521 coating promoted } \\
\text { robust renewal and the addition } \\
\text { with E-cadherin permitted } \\
\text { efficient clonal expansion }\end{array}$ & Rodin et al., 2014 \\
\hline embryo & human & ESCs/iPSCs & cell counting & $\begin{array}{l}\text { LM coating promoted cell } \\
\text { proliferation }\end{array}$ & Lam et al., 2012 \\
\hline embryo & human & ESCs/iPSCs & cell counting & $\begin{array}{l}\text { LM-E8 fragments from LM } \\
\text { isoforms supported cell } \\
\text { proliferation }\end{array}$ & Miyazaki et al., 2012 \\
\hline embryo & human & ESCs/iPSCs & $\begin{array}{l}\text { cell counting } \\
\text { and Ki67+ cells }\end{array}$ & $\begin{array}{l}\text { Knockdown of LM- } \alpha 5 \text { gene } \\
\text { diminished cell proliferation }\end{array}$ & Laperle et al., 2015 \\
\hline embryo & mouse & NSPCs & $\begin{array}{c}\text { neurosphere } \\
\text { and cell } \\
\text { counting } \\
\end{array}$ & $\begin{array}{l}\text { LM coating increased cell } \\
\text { number and neurosphere size }\end{array}$ & Flanagan et al., 2006 \\
\hline embryo & mouse & ESCs & cell counting & $\begin{array}{l}\text { LM-511 or LM-332 promoted } \\
\text { cell proliferation }\end{array}$ & $\begin{array}{c}\text { Domogatskaya et al., } \\
2008\end{array}$ \\
\hline embryo & mouse & ESCs & $\begin{array}{l}\text { proliferation } \\
\text { index by flow } \\
\text { cytometry }\end{array}$ & $\begin{array}{l}\text { LM-111 coating promoted cell } \\
\text { proliferation }\end{array}$ & Suh et al., 2012 \\
\hline
\end{tabular}




\section{The effect of laminin on chondrogenesis}

It is well known that chondrocytes maintain phenotype and function by regulating specific markers, such as collagen type II and sulfated glycosaminoglycans (GAGs) (von der Mark and Conrad, 1979). Schminke et al. (2016) found that laminin could significantly upregulate the level of COL2A1 (collagen type II gene) and reduce the level of COL1A1 (collagen type I gene) in healthy and osteoarthritic chondrocytes. Laminin-presenting hydrogels can markedly promote the production of sulfated GAGs in NP cells (Francisco et al., 2014; Gilchrist et al., 2011b). In a pellet culture system, Toh et al. (2013) reported an orderly spatiotemporal shift in expression of laminin from a diffuse territorial and interterritorial distribution to a defined pericellular localization, following chondrogenic induction of bone marrow-derived MSCs. Further studies also showed that laminins directly upregulated COL2A1 expression in human chondrogenic progenitor cells and GAG content in human MSCs (Lindner et al., 2010; Schminke et al., 2016), indicating that laminins have essential roles in promoting chondrogenesis of cartilage-forming cells. However, some studies found that laminins were differentially expressed with an obvious trend: an increase in cell aggregation during development followed by a decrease during chondrogenesis (Tavella et al., 1997; Toh et al., 2013). Moreover, the expression of laminins exists in developing and normal cartilage but disappears in degenerative, traumatically-damaged cartilage and in cartilage that fails clinical repair, suggesting a spatiotemporal distribution and function of laminins in chondrogenesis (Foldager et al., 2004; Foldager et al., 2016). Growing evidence shows that ECM components can induce chondrogenic differentiation in chick embryo limb-bud mesenchymal cells and human MSCs, but laminin alone fails to drive chondrogenic activity (Bradham et al., 1995; Matsubara et al., 2004), suggesting that laminins might participate in the process of chondrogenesis with other regulatory factors. For instance, LM-332 promotes proliferation but suppresses chondrogenic differentiation (Lindner et al., 2010) by regulating integrin $\alpha 3 \beta 1$ activities in human MSCs and mouse ATDC5 cells (Hashimoto et al., 2005; Hashimoto et al., 2006), while favorably enhancing osteogenesis via an integrin/FAK/ERK1/2 signaling pathway (Salasznyk et al., 2007). Despite these studies that suggest the roles of laminins in chondrogenesis, the dynamic expression of various laminin isoforms and their functions during chondrogenesis has not been fully delineated. It is likely that the expression of laminins is highly regulated during proliferation and differentiation and specific laminin isoforms could be involved in lineage-specific differentiation. Looking ahead, a better understanding of laminin expression and its functions would likely enable better control of chondrogenesis.

\section{Conclusions and perspectives}

As critical components of ECM, laminins play important roles in providing a favorable microenvironment for cartilage regeneration. In this review, there is increasing evidence showing that laminins, secreted by chondrocytes and primarily located in the PCM in cartilage and cartilage-like tissues, are involved in the regulation of chondrocyte activities, such as adhesion, migration and survival. Furthermore, the role of laminins in stem cell proliferation and chondrogenic differentiation was fully discussed. Also, recent studies have shown that modification of scaffolds with laminins can improve the biological activity of cartilage-forming cells for tissue engineering and applications (Francisco et al., 2014; Gilchrist et al., 2011b). Despite efforts to delineate the expression of laminins during chondrogenesis, our understanding of laminins in terms of their regulation, expression and function during chondrogenesis is still limited. Looking ahead, elucidating the spatiotemporal expression and function of specific laminin isoforms and their receptors in stem cell proliferation and lineagespecific differentiation would enable better control of chondrogenesis and greatly benefit the future clinical exploration of laminins in cell therapy for cartilage injuries and osteoarthritis (Toh et al., 2016a).

Some limitations exist to prevent further investigations in cell-laminin interaction and potential clinical application. For example, laminins in various isoforms are present in low concentrations and are highly cross-linked within the ECM, making it difficult to extract them from tissues or purify them from cell supernatant. Due to their large size and higher-order structure, recombinantly expressed laminins, different from their native form, are not easily obtained. Thus, the exploration of native laminin to uncover the "real" roles of laminins in cartilage regeneration is necessary. Fortunately, a recent report shows that recombinant E8 fragments of laminin isoforms (LM-E8s), which are the minimum fragments conferring integrin-binding activity, promote more robust adhesion of human ESCs and iPSCs than Matrigel and intact laminin isoforms (Miyazaki et al., 2012). LM-E8s maintain long-term self-renewal, high-level expression of pluripotency markers and differentiation capacity into all three germ layers (Miyazaki et al., 2012). Since LM-E8s are much smaller and easier to produce recombinantly and purify than intact laminins, this finding indicates that LM-E8s, the minimum structure harboring the full integrin-binding activity of laminins, are remarkable substrates for the long-term culture of human ESCs, with a significant advantage over intact laminin isoforms, such as LM-511 and LM-332 (Miyazaki et al., 2012).

In addition, the focus of current efforts is mainly on the use of a laminin-coated 2D culture environment, 
which is different from in vivo 3D chondrogenesis. Increasing evidence indicates that decellularized extracellular matrix (dECM), deposited by stem cells and primary cells, provides an excellent in vitro 3D model, mimicking the organization of native ECM in vivo and can rejuvenate stem cell proliferation and chondrogenic differentiation (Pei et al., 2011). The in vitro genetic modification model, which uses overexpression and knockout of targeted genes, can facilitate investigation of the functionality of specific laminin isoforms in a 3D environment on stem cell biological activity, such as proliferation and chondrogenic differentiation.

\section{Acknowledgements}

We thank Suzanne Danley for editing the manuscript. This project was supported by Research Grants from the Musculoskeletal Transplant Foundation (MTF), the National Institutes of Health (1R03AR06276301A1 \& 1R01AR067747-01A1) (to M.P.) and Study Abroad Scholarship from Jiangsu Province and Subei People's Hospital of Jiangsu Province (to Y.S.).

\section{References}

Abay N, Gurel Pekozer G, Ramazanoglu M, Kose GT (2016) Bone formation from porcine dental germ stem cells on surface modified polybutylene succinate scaffolds. Stem Cells Int 2016: 8792191.

Addington CP, Pauken CM, Caplan MR, Stabenfeldt SE (2014) The role of SDF-1 $\alpha$-ECM crosstalk in determining neural stem cell fate. Biomaterials 35: 3263-3272.

Aigner T, Stöve J (2003) Collagens-major component of the physiological cartilage matrix, major target of cartilage degeneration, major tool in cartilage repair. Adv Drug Deliv Rev 55: 1569-1593.

Arulmoli J, Wright HJ, Phan DT, Sheth U, Que RA, Botten GA, Keating M, Botvinick EL, Pathak MM, Zarembinski TI, Yanni DS, Razorenova OV, Hughes CC, Flanagan LA (2016) Combination scaffolds of salmon fibrin, hyaluronic acid and laminin for human neural stem cell and vascular tissue engineering. Acta Biomater 43: 122-138.

Aumailley M (2013) The laminin family. Cell Adh Migr 7: 48-55.

Aumailley M, Rousselle P (1999) Laminins of the dermo-epidermal junction. Matrix Biol 18: 19-28.

Bernhard JC, Vunjak-Novakovic G (2016) Should we use cells, biomaterials, or tissue engineering for cartilage regeneration?. Stem Cell Res Ther 7: 56.

Boonen KJ, Post MJ (2008) The muscle stem cell niche: regulation of satellite cells during regeneration. Tissue Eng Part B Rev 14: 419-431.

Bradham DM, Passaniti A, Horton WE Jr (1995) Mesenchymal cell chondrogenesis is stimulated by basement membrane matrix and inhibited by ageassociated factors. Matrix Biol 14: 561-571.
Bridgen DT, Gilchrist CL, Richardson WJ, Isaacs RE, Brown CR, Yang KL, Chen J, Setton LA (2013) Integrin-mediated interactions with extracellular matrix proteins for nucleus pulposus cells of the human intervertebral disc. J Orthop Res 31: 1661-1667.

Brynda E, Houska M, Kysilka J, Prádný M, Lesný P, Jendelová P, Michálek J, Syková E (2009) Surface modification of hydrogels based on poly(2hydroxyethyl methacrylate) with extracellular matrix proteins. J Mater Sci Mater Med 20: 909-915.

Bulić K (1996) Articular chondrocytes interact with basement membrane Matrigel through laminin active binding sites. Acta Med Croatica 50: 69-74.

Candela ME, Yasuhara R, Iwamoto M, EnomotoIwamoto M (2014) Resident mesenchymal progenitors of articular cartilage. Matrix Biol 39: 44-49.

Celebi B, Mantovani D, Pineault N (2011) Effects of extracellular matrix proteins on the growth of haematopoietic progenitor cells. Biomed Mater 6: 055011.

Chen J, Jing L, Gilchrist CL, Richardson WJ, Fitch RD, Setton LA (2009) Expression of laminin isoforms, receptors and binding proteins unique to nucleus pulposus cells of immature intervertebral disc. Connect Tissue Res 50: 294-306.

Choi BH, Choi YS, Kang DG, Kim BJ, Song YH, Cha HJ (2010) Cell behavior on extracellular matrix mimic materials based on mussel adhesive protein fused with functional peptides. Biomaterials 31: 89808988.

Chu WC, Zhang S, Sng TJ, Ong YJ, Tan WL, Ang VY, Foldager CB, Toh WS (2017) Distribution of pericellular matrix molecules in the temporomandibular joint and their chondroprotective effects against inflammation. Int J Oral Sci 9: 43-52.

Colognato H, Yurchenco PD (2000) Form and function: the laminin family of heterotrimers. Dev Dyn 218: 213-234.

Connelly JT, Petrie TA, García AJ, Levenston ME (2011) Fibronectin- and collagen-mimetic ligands regulate bone marrow stromal cell chondrogenesis in three-dimensional hydrogels. Eur Cell Mater 22: 168-177.

Crane JF, Trainor PA (2006) Neural crest stem and progenitor cells. Annu Rev Cell Dev Biol 22: 267-286.

Domogatskaya A, Rodin S, Boutaud A, Tryggvason K (2008) Laminin-511 but not $-332,-111$, or -411 enables mouse embryonic stem cell self-renewal in vitro. Stem Cells 26: 2800-2809.

Dürr J, Lammi P, Goodman SL, Aigner T, von der Mark K (1996) Identification and immunolocalization of laminin in cartilage. Exp Cell Res 222: 225-233.

Eble JA (2001) The molecular basis of integrinextracellular matrix interactions. Osteoarthritis Cartilage 9 Suppl A: S131-40.

Ekblom P, Lonai P, Talts JF (2003) Expression and biological role of laminin-1. Matrix Biol 22: 35-47.

Flanagan LA, Rebaza LM, Derzic S, Schwartz PH, Monuki ES (2006) Regulation of human neural precursor cells by laminin and integrins. J Neurosci Res 83: 845-856. 
Foldager CB, Toh WS, Christensen BB, Lind M, Gomoll AH, Spector M (2016) Collagen type IV and laminin expressions during cartilage repair and in late clinically failed repair tissues from human subjects. Cartilage 7: 52-61.

Foldager CB, Toh WS, Gomoll AH, Olsen BR, Spector M (2014) Distribution of basement membrane molecules, laminin and collagen type IV, innormal and degenerated cartilage tissues. Cartilage 5: 123132.

Francisco AT, Hwang PY, Jeong CG, Jing L, Chen J, Setton LA (2014) Photocrosslinkable lamininfunctionalized polyethylene glycol hydrogel for intervertebral disc regeneration. Acta Biomater 10: 1102-1111.

Francisco AT, Mancino RJ, Bowles RD, Brunger JM, Tainter DM, Chen YT, Richardson WJ, Guilak F, Setton LA (2013) Injectable laminin-functionalized hydrogel for nucleus pulposus regeneration. Biomaterials 34: 7381-7388.

Fuchs E (2009) Finding one's niche in the skin. Cell Stem Cell 4: 499-502.

Fuerst FC, Gruber G, Stradner MH, Jones JC, Kremser ML, Angerer H, Setznagl D, Glehr M, Windhager R, Leithner A, Graninger WB (2011) Regulation of MMP3 by laminin alpha 4 in human osteoarthritic cartilage. Scand J Rheumatol 40: 494496.

Gilchrist CL, Chen J, Richardson WJ, Loeser RF, Setton LA (2007) Functional integrin subunits regulating cell-matrix interactions in the intervertebral disc. J Orthop Res 25: 829-840.

Gilchrist CL, Darling EM, Chen J, Setton LA (2011b) Extracellular matrix ligand and stiffness modulate immature nucleus pulposus cell-cell interactions. PLoS One 6: e27170.

Gilchrist CL, Francisco AT, Plopper GE, Chen J, Setton LA (2011a) Nucleus pulposus cell-matrix interactions with laminins. Eur Cell Mater 21: 523-532.

Gorfu G, Virtanen I, Hukkanen M, Lehto VP, Rousselle P, Kenne E, Lindbom L, Kramer R, Tryggvason K, Patarroyo M (2008) Laminin isoforms of lymph nodes and predominant role of alpha5laminin(s) in adhesion and migration of blood lymphocytes. J Leukoc Biol 84: 701-12.

Gronthos S, Simmons PJ, Graves SE, Robey PG (2001) Integrin-mediated interactions between human bone marrow stromal precursor cells and the extracellular matrix. Bone 28: 174-181.

Gu J, Fujibayashi A, Yamada KM, Sekiguchi K (2002) Laminin-10/11 and fibronectin differentially prevent apoptosis induced by serum removal via phosphatidylinositol 3-kinase/Akt- and MEK1/ERKdependent pathways. J Biol Chem 277: 19922-19928.

Hall PE, Lathia JD, Caldwell MA, FfrenchConstant C (2008) Laminin enhances the growth of human neural stem cells in defined culture media. BMC Neurosci 9: 71.

Hall TE, Bryson-Richardson RJ, Berger S, Jacoby AS, Cole NJ, Hollway GE, Berger J, Currie PD (2007) The zebrafish candyfloss mutant implicates extracellular matrix adhesion failure in laminin alpha2-deficient congenital muscular dystrophy. Proc Natl Acad Sci USA 104: 7092-7097.

Hashimoto J, Kariya Y, Miyazaki K (2006) Regulation of proliferation and chondrogenic differentiation of human mesenchymal stem cells by laminin-5 (laminin-332). Stem Cells 24: 2346-2354.

Hashimoto J, Ogawa T, Tsubota Y, Miyazaki K (2005) Laminin-5 suppresses chondrogenic differentiation of murine teratocarcinoma cell line ATDC5. Exp Cell Res 310: 256-269.

Häusler G, Helmreich M, Marlovits S, Egerbacher M (2002) Integrins and extracellular matrix proteins in the human childhood and adolescent growth plate. Calcif Tissue Int 71: 212-218.

Hayes AJ, Benjamin M, Ralphs JR (2001) Extracellular matrix in development of the intervertebral disc. Matrix Biol 20: 107-121.

He L, Tang S, Prabhakaran MP, Liao S, Tian L, Zhang Y, Xue W, Ramakrishna S (2013) Surface modification of PLLA nano-scaffolds with laminin multilayer by LbL assembly for enhancing neurite outgrowth. Macromol Biosci 13: 1601-1609.

Heydarkhan-Hagvall S, Gluck JM, Delman C, Jung M, Ehsani N, Full S, Shemin RJ (2012) The effect of vitronectin on the differentiation of embryonic stem cells in a 3D culture system. Biomaterials 33: 20322040.

Hohenester E, Yurchenco PD (2013) Laminins in basement membrane assembly. Cell Adh Migr 7: 5663.

Ishibashi H, Takenoshita Y, Ishibashi K, Oka M (1996) Expression of extracellular matrix in human mandibular condyle. Oral Surg Oral Med Oral Pathol Oral Radiol Endod 81: 402-414.

Jeng L, Hsu HP, Spector M (2013) Tissueengineered cartilaginous constructs for the treatment of caprine cartilage defects, including distribution of laminin and type IV collagen.Tissue Eng Part A 19: 2267-2274.

Jeng L, Olsen BR, Spector M (2012) Engineering endostatin-expressing cartilaginous constructs using injectable biopolymer hydrogels. Acta Biomater 8: 2203-2212.

Kang BJ, Ryu HH, Park SS, Kim Y, Woo HM, Kim WH, Kweon OK (2012) Effect of Matrigel on the osteogenic potential of canine adipose tissue-derived mesenchymal stem cells. J Vet Med Sci 74: 827-836.

Keller V, Deiwick A, Pflaum M, Schlie-Wolter $S$ (2016) Correlation between ECM guidance and actin polymerization on osteogenic differentiation of human adipose-derived stem cells. Exp Cell Res 347: 339-349.

Ko JY, Kim KI, Park S, Im GI (2014) In vitro chondrogenesis and in vivo repair of osteochondral defect with human induced pluripotent stem cells. Biomaterials 35: 3571-3581.

Komura T, Kato K, Konagaya S, NakajiHirabayashi T, Iwata H (2015) Optimization of surface-immobilized extracellular matrices for the proliferation of neural progenitor cells derived from 
induced pluripotent stem cells. Biotechnol Bioeng 112: 2388-2396.

Köllmer M, Keskar V, Hauk TG, Collins JM, Russell B, Gemeinhart RA (2012) Stem cell-derived extracellular matrix enables survival and multilineage differentiation within superporous hydrogels. Biomacromolecules 13: 963-973.

Kvist AJ, Nyström A, Hultenby K, Sasaki T, Talts JF, Aspberg A (2008) The major basement membrane components localize to the chondrocyte pericellular matrix-a cartilage basement membrane equivalent? Matrix Biol 27: 22-33.

Lam MT, Longaker MT (2012) Comparison of several attachment methods for human iPS, embryonic and adipose-derived stem cells for tissue engineering. J Tissue Eng Regen Med 6 Suppl 3: s8086.

Laperle A, Hsiao C, Lampe M, Mortier J, Saha K, Palecek SP, Masters KS (2015) $\alpha$-5 laminin synthesized by human pluripotentstem cells promotes selfrenewal. Stem Cell Reports 5: 195-206.

Laurent M, Martinerie C, Thibout H, Hoffman MP, Verrecchia F, Le Bouc Y, Mauviel A, Kleinman HK (2003) NOVH increases MMP3 expression and cell migration in glioblastoma cells via a PDGFR-alphadependent mechanism. FASEB J 17: 1919-1921.

Lee SK, Malpeli M, Cancedda R, Utani A, Yamada Y, Kleinman HK (1997) Laminin chain expression by chick chondrocytes and mouse cartilaginous tissues in vivo and in vitro. Exp Cell Res 236: 212-222.

Leiton CV, Aranmolate A, Eyermann C, Menezes MJ, Escobar-Hoyos LF, Husain S, Winder SJ, Colognato H (2015) Laminin promotes metalloproteinasemediated dystroglycan processing to regulate oligodendrocyte progenitor cell proliferation. J Neurochem 135: 522-538.

Li J, Hansen KC, Zhang Y, Dong C, Dinu CZ, Dzieciatkowska M, Pei M (2014) Rejuvenation of chondrogenic potential in a young stem cell microenvironment. Biomaterials 35: 642-653.

Li J, Pei M (2012) Cell senescence: a challenge in cartilage engineering and regeneration. Tissue Eng Part B Rev 18: 270-287.

Li Y, Wang Y, Yu L, Sun C, Cheng D, Yu S, Wang Q, Yan Y, Kang C, Jin S, An T, Shi C, Xu J, Wei C, Liu J, Sun J, Wen Y, Zhao S, Kong Y (2013) miR-146b-5p inhibits glioma migration and invasion by targeting MMP16. Cancer Lett 339: 260-269.

Lindner U, Kramer J, Behrends J, Driller B, Wendler NO, Boehrnsen F, Rohwedel J, Schlenke P (2010) Improved proliferation and differentiation capacity of human mesenchymal stromal cells cultured with basement-membrane extracellular matrix proteins. Cytotherapy 12: 992-1005.

Loeser RF (2014) Integrins and chondrocytematrix interactions in articular cartilage. Matrix Biol 39: 11-16.

Lu P, Takai K, Weaver VM, Werb Z (2011) Extracellular matrix degradation and remodeling in development and disease. Cold Spring Harb Perspect Biol 3: a005058.
Lu W, Miyazaki K, Mizushima H, Nemoto N (2001) Immunohistochemical distribution of laminin-5 gamma2 chain and its developmental change in human embryonic and foetal tissues. Histochem J 33: 629-637.

Lynch K, Pei M (2014) Age associated communication between cells and matrix: a potential impact on stem cell-based tissue regeneration strategies. Organogenesis 10: 289-298.

Mathews S, Bhonde R, Gupta PK, Totey S (2012) Extracellular matrix protein mediated regulation of the osteoblast differentiation of bone marrow derived human mesenchymal stem cells. Differentiation 84: 185-192.

Matsubara T, Tsutsumi S, Pan H, Hiraoka H, Oda R, Nishimura M, Kawaguchi H, Nakamura K, Kato Y (2004) A new technique to expand human mesenchymal stem cells using basement membrane extracellular matrix. Biochem Biophys Res Commun 313: 503-508.

Miyazaki T, Futaki S, Suemori H, Taniguchi Y, Yamada M, Kawasaki M, Hayashi M, Kumagai H, Nakatsuji N, Sekiguchi K, Kawase E (2012) Laminin E8 fragments support efficient adhesion and expansion of dissociated human pluripotent stem cells. Nat Commun 3: 1236.

Moazedi-Fuerst FC, Gruber G, Stradner $\mathrm{MH}$, Guidolin D, Jones JC, Bodo K, Wagner K, Peischler D, Krischan V, Weber J, Sadoghi P, Glehr M, Leithner A, Graninger WB (2016) Effect of laminin-A4 inhibition on cluster formation of human osteoarthritic chondrocytes. J Orthop Res 34: 419-426.

Mobasheri A, Kalamegam G, Musumeci G, Batt ME (2014) Chondrocyte and mesenchymal stem cellbased therapies for cartilage repair in osteoarthritis and related orthopaedic conditions. Maturitas 78: 188-198.

Nettles DL, Richardson WJ, Setton LA (2004) Integrin expression in cells of the intervertebral disc. J Anat 204: 515-520.

Nguyen-Ngoc KV, Cheung KJ, Brenot A, Shamir ER, Gray RS, Hines WC, Yaswen P, Werb Z, Ewald AJ (2012) ECM microenvironment regulates collective migration and local dissemination in normal and malignant mammary epithelium. Proc Natl Acad Sci USA 109: E2595-604.

Ode A, Duda GN, Glaeser JD, Matziolis G, Frauenschuh S, Perka C, Wilson CJ, Kasper G (2010) Toward biomimetic materials in bone regeneration: functional behavior of mesenchymal stem cells on a broad spectrum of extracellular matrix components. J Biomed Mater Res A 95: 1114-1124.

Ortinau S, Schmich J, Block S, Liedmann A, Jonas L, Weiss DG, Helm CA, Rolfs A, Frech MJ (2010) Effect of 3D-scaffold formation on differentiation and survival in human neural progenitor cells. Biomed Eng Online 9: 70.

Pei M (2017) Environmental preconditioning rejuvenates adult stem cells' proliferation and chondrogenic potential. Biomaterials 117: 10-23. 
Pei M, Li JT, Shoukry M, Zhang Y (2011) A review of decellularized stem cell matrix: a novel cell expansion system for cartilage tissue engineering. Eur Cell Mater 22: 333-343.

Petz M, Them N, Huber H, Beug H, Mikulits W (2012) La enhances IRES-mediated translation of laminin B1 during malignant epithelial to mesenchymal transition. Nucleic Acids Res 40: 290302.

Pizzute T, Li J, Zhang Y, Davis ME, Pei M (2016) Fibroblast growth factor ligand dependent proliferation and chondrogenic differentiation of synovium-derived stem cells and concomitant adaptation of Wnt/mitogen-activated protein kinase signals. Tissue Eng Part A 22: 1036-1046.

Poole CA, Flint MH, Beaumont BW (1984) Morphological and functional interrelationships of articular cartilage matrices. J Anat 138: 113-138.

Qian L, Saltzman WM (2004) Improving the expansion and neuronal differentiation of mesenchymal stem cells through culture surface modification. Biomaterials 25: 1331-1337.

Rodin S, Antonsson L, Niaudet C, Simonson OE, Salmela E, Hansson EM, Domogatskaya A, Xiao Z, Damdimopoulou P, Sheikhi M, Inzunza J, Nilsson AS, Baker D, Kuiper R, Sun Y, Blennow E, Nordenskjöld M, Grinnemo KH, Kere J, Betsholtz C, Hovatta O, Tryggvason K (2014) Clonal culturing of human embryonic stem cells on laminin-521/E-cadherin matrix in defined and xeno-free environment. Nat Commun 5: 3195.

Rodin S, Domogatskaya A, Ström S, Hansson EM, Chien KR, Inzunza J, Hovatta O, Tryggvason K (2010) Long-term self-renewal of human pluripotent stem cells on human recombinant laminin-511. Nat Biotechnol 28: 611-615.

Roelofs AJ, Rocke JP, De Bari C (2013) Cellbased approaches to joint surface repair: a research perspective. Osteoarthritis Cartilage 21: 892-900.

Salasznyk RM, Klees RF, Boskey A, Plopper GE (2007) Activation of FAK is necessary for the osteogenic differentiation of human mesenchymal stem cells on laminin-5. J Cell Biochem 100: 499-514.

Salter DM, Godolphin JL, Gourlay MS (1995) Chondrocyte heterogeneity: immunohistologically defined variation of integrin expression at different sites in human fetal knees. J Histochem Cytochem 43: 447-457

Schéele S, Nyström A, Durbeej M, Talts JF, Ekblom M, Ekblom P (2007) Laminin isoforms in development and disease. J Mol Med (Berl) 85: 825-836.

Schminke B, Frese J, Bode C, Goldring MB, Miosge $N$ (2016) Laminins and nidogens in the pericellular matrix of chondrocytes: their role in osteoarthritis and chondrogenic differentiation. Am J Pathol 186: 410-418.

Seeger T, Hart M, Patarroyo M, Rolauffs B, Aicher WK, Klein G (2015) Mesenchymal stromal cells for sphincter regeneration: role of laminin isoforms upon myogenic differentiation. PLoS One 10: e0137419.
Silbermann M, von der Mark K, Heinegard D (1990) An immunohistochemical study of the distribution of matrical proteins in the mandibular condyle of neonatal mice. II. Non-collagenous proteins. J Anat 170: 23-31.

Somoza RA, Welter JF, Correa D, Caplan AI (2014) Chondrogenic differentiation of mesenchymal stem cells: challenges and unfulfilled expectations. Tissue Eng Part B Rev 20: 596-608.

Stoffels JM, Zhao C, Baron W (2013) Fibronectin in tissue regeneration: timely disassembly of the scaffold is necessary to complete the build. Cell Mol Life Sci 70: 4243-4253.

Suh HN, Kim MO, Han HJ (2012) Laminin-111 stimulates proliferation of mouse embryonic stem cells through a reduction of gap junctional intercellular communication via RhoA-mediated Cx43 phosphorylation and dissociation of Cx43/ZO-1/ drebrin complex. Stem Cells Dev 21: 2058-2070.

SundarRaj N, Fite D, Ledbetter S, Chakravarti S, Hassell JR (1995) Perlecan is a component of cartilage matrix and promotes chondrocyte attachment. J Cell Sci 108 (Pt 7): 2663-2672.

Szymczak P, Wojcik-Stanaszek L, Sypecka J, Sokolowska A, Zalewska T (2010) Effect of matrix metalloproteinases inhibition on the proliferation and differentiation of HUCB-NSCs cultured in the presence of adhesive substrates. Acta Neurobiol Exp (Wars) 70: 325-336.

Tavella S, Bellese G, Castagnola P, Martin I, Piccini D, Doliana R, Colombatti A, Cancedda R, Tacchetti C (1997) Regulated expression of fibronectin, laminin and related integrin receptors during the early chondrocyte differentiation. J Cell Sci 110: 2261-2270.

Toh WS, Brittberg M, Farr J, Foldager CB, Gomoll AH, Hui JH, Richardson JB, Roberts S, Spector M (2016b) Cellular senescence in aging and osteoarthritis. Acta Orthop 87 : 6-14.

Toh WS, Foldager CB, Hui JH, Olsen BR, Spector M (2016a) Exploiting stem cell-extracellular matrix interactions for cartilage regeneration: a focus on basement membrane molecules. Curr Stem Cell Res Ther 11: 618-625.

Toh WS, Foldager CB, Pei M, Hui JH (2014) Advances in mesenchymal stem cell-based strategies for cartilage repair and regeneration. Stem Cell Rev 10: 686-696.

Toh WS, Foldager CB, Olsen BR, Spector M (2013) Basement membrane molecule expression attendant to chondrogenesis by nucleus pulposus cells and mesenchymal stem cells. J Orthop Res 31: 1136-1143.

Toh WS, Lim TC, Kurisawa M, Spector M (2012) Modulation of mesenchymal stem cell chondrogenesis in a tunable hyaluronic acid hydrogel microenvironment. Biomaterials 33: 3835-3845.

Toh WS, Lee EH, Guo XM, Chan JK, Yeow $\mathrm{CH}$, Choo AB, Cao $\mathrm{T}$ (2010) Cartilage repair using hyaluronan hydrogel-encapsulated human embryonic stem cell-derived chondrogenic cells. Biomaterials 31: 6968-6980. 
Ustünel I, Sahin Z, Akkoyunlu G, Demir R (2003a) The zonal distributions of alkaline phosphatase, adenosine triphosphatase, laminin, fibronectin and chondroitin 4-sulphate in growing rat humerus proximal epiphyseal cartilage: a histochemical and an immunohistochemical study. Anat Histol Embryol 32: 356-361.

Ustünel I, Cayli S, Güney K, Celik-Ozenci C, Tanriöver G, Sahin Z, Balkan E, Demir R (2003b) Immunohistochemical distribution patterns of collagen type II, chondroitin 4-sulfate, laminin and fibronectin in human nasal septal cartilage. Acta Histochem 105: 109-114.

von der Mark K, Conrad G (1979) Cartilage cell differentiation: review. Clin Orthop Relat Res 139: 185-205.

Vuoristo S, Virtanen I, Takkunen M, Palgi J, Kikkawa Y, Rousselle P, Sekiguchi K, Tuuri T, Otonkoski T (2009) Laminin isoforms in human embryonic stem cells: synthesis, receptor usage and growth support. J Cell Mol Med 13: 2622-2633.

Wilusz RE, Sanchez-Adams J, Guilak F (2014) The structure and function of the pericellular matrix of articular cartilage. Matrix Biol 39: 25-32.

Yamada M, Sekiguchi K (2015) Molecular basis of laminin-integrin interactions. Curr Top Membr 76: 197-229.

Zhang Y, Pizzute T, Li J, He F, Pei M (2015) sb203580 preconditioning recharges matrix-expanded human adult stem cells for chondrogenesis in an inflammatory environment - a feasible approach for autologous stem cell based osteoarthritic cartilage repair. Biomaterials 64: 88-97.

\section{Discussion with Reviewer}

Roberto Narcisi: Are there any reports indicating the role of mechanical stimulation on laminin expression? Authors: Few reports are available to indicate the role of mechanical stimulation in laminin expression. One is by Ulbrich et al. (2010), who found that microgravity did not influence laminin and collagen type IV expression in human chondrocytes.
Roberto Narcisi: Is there any evidence that TGF $\beta$ signaling can influence laminin expression in stem cells or chondrocytes?

Authors: Yes. Some reports indicate that TGF $\beta$ signaling can influence laminin expression in stem cells or chondrocytes. For example, Toh et al. (2013) found that, under chondrogenic induction with TGF $\beta 1$, the percentages of NP cells and bone marrow stromal cells (BMSCs) in pellets with pericellular staining of laminin increased compared with no TGF $\beta 1$ treatment. Korecki et al. (2010) found that the expression level of laminin $\beta 1$ increased when human BMSCs were exposed to chondrogenic medium with TGF 33 or notochordal cell-conditioned medium.

Roberto Narcisi: Are there any data available on the effect of laminin silencing or overexpression on stem cell differentiation and proliferation?

Authors: Yes, but only a few publications. Laperle et al. (2015) indicated that inducible shRNA knockdown and Cas9-mediated disruption of $L A M A 5$ dramatically reduced hPSC self-renewal and increased apoptosis without affecting the expression of pluripotency markers. Increased self-renewal and survival was restored to wild-type levels by culturing LAMA5deficient cells on exogenous laminin-521.

\section{Additional References}

Korecki CL, Taboas JM, Tuan RS, Iatridis JC (2010) Notochordal cell conditioned medium stimulates mesenchymal stem cell differentiation toward a young nucleus pulposus phenotype. Stem Cell Res Ther 1: 18.

Ulbrich C, Westphal K, Pietsch J, Winkler HD, Leder A, Bauer J, Kossmehl P, Grosse J, Schoenberger J, Infanger M, Egli M, Grimm D (2010) Characterization of human chondrocytes exposed to simulated microgravity. Cell Physiol Biochem. 25: 551-560.

Editor's note: The Scientific Editor responsible for this paper was Martin Stoddart. 